\title{
Formulation and storage studies of herbal based RTS beverages from persimmon (Diospyros kaki L.) fruit
}

\author{
Anjali Gautam, Anju K. Dhiman, Surekha Attri and Deepika Kathuria \\ Department of Food Science and Technology, Dr YS Parmar University of Horticulture and Forestry, Nauni, Solan-173230, HP, India
}

\begin{tabular}{|c|c|}
\hline Article Info & Abstract \\
\hline $\begin{array}{l}\text { Article history } \\
\text { Received } 6 \text { August } 2020 \\
\text { Revised } 1 \text { October } 2020 \\
\text { Accepted } 5 \text { October } 2020 \\
\text { Published online } 30 \text { December } 2020\end{array}$ & $\begin{array}{l}\text { A ready-to-serve (RTS) beverage was developed using pulp, extracted by the cold and hot pulping } \\
\text { method. Among different combinations of TSS }\left(10,12,15^{\circ} \text { Brix }\right) \text {, pulp concentration }(10,15,20 \%) \\
\text { and acidity }(0.2,0.3,0.4 \%) \text { beverage developed in which treatment } \mathrm{T}_{5} \text { at } 10^{\circ} \text { Brix using cold extracted } \\
\text { pulp and in treatment } \mathrm{T}_{2} \text { at } 12^{\circ} \text { Brix using hot extracted pulp was found to be the best on the basis of } \\
\text { sensory evaluation. They exhibited ascorbic acid }(2.26 \text { and } 1.44 \mathrm{mg} / 100 \mathrm{~g}), \beta \text {-carotene }(0.040 \text { and }\end{array}$ \\
\hline $\begin{array}{l}\text { Keywords } \\
\text { Rite persimmon } \\
\text { RTS } \\
\text { Herbal RTS } \\
\text { Storage } \\
\text { Quality evaluation } \\
\text { Ginger }\end{array}$ & $\begin{array}{l}0.054 \mu \mathrm{g} / 100 \mathrm{~g}) \text { and total phenols }(0.58 \text { and } 0.55 \mathrm{mg} / 100 \mathrm{~g}) \text {. Further, comparing the nutritional and } \\
\text { sensory characteristics of the RTS beverage, the use of hot extracted pulp was selected for the preparation } \\
\text { of herbal RTS beverage (ginger, ginger-mint). Persimmon RTS beverage was evaluated for quality and } \\
\text { stability during storage. Though, sensory scores decreased significantly with the advancement of storage } \\
\text { but processed products of all the treatments were well above the acceptable limits. The study indicated } \\
\text { that the RTS beverage can be stored safely for a period of six months with minimal changes in chemical } \\
\text { and sensory attributes. }\end{array}$ \\
\hline
\end{tabular}

\section{Introduction}

Different types of RTS beverages available in the market include synthetic, carbonated, fruit juice based, etc. The pulp/juice extracted from fruits and vegetables when used to prepare beverage is usually referred to as fruit beverage. The nutritive value of fruit based beverages is much more than that of the synthetic products. If, synthetic drinks are substituted with fruit beverages, it would be beneficial to the consumers as well as to the fruit growers. Different researchers had used different fruits for the preparation of RTS beverages. Ripe pumpkin based RTS beverage was developed by Dhiman et al. (2017) by using various combinations of pulp $(10,13,15$ and $17 \%)$ and TSS (10, 13 and $15^{\circ}$ Brix) with lime, hill lemon and citric acid as acidulants. Mulberry (Morus alba L.) RTS was prepared by Hamid et al. (2017) with different combinations of juice $(8,10,12,14$ and $16 \%)$ and TSS (12 and $15^{\circ}$ Brix). The RTS beverage prepared with different combinations of juice $(10,12,14$ and $16 \%$ ) and TSS (12 and $15^{\circ}$ Brix) from wild aonla (Phyllanthus emblica L.) was evaluated for quality by Thakur et al. (2018). In addition, novel techniques are also involved for the processing of beverages. Nguyen (2020) prepared dragon fruit beverage using acoustic treatment by varying acoustic power, duration and

Corresponding author: Ms. Deepika Kathuria Department of Food Science and Technology, Dr YS Parmar University of Horticulture and Forestry, Nauni, Solan, HP 173230, India E-mail: deepukathuria@gmail.com

Tel.: +91-9756533626 temperature. Further, incorporation of herbal extracts in RTS beverage helps in maintaining health and treating chronic diseases (Alam, 2019). Dhiman et al. (2017) also developed ginger, mint, ginger-mint flavoured RTS beverages using ripe pumpkin pulp. Looking upon the demand for natural beverages, there exists a great scope for the preparation of beverages by utilizing fruit juices and pulps.

Persimmon (Diospyros kaki L.) is a fleshy fibrous perennial and sub tropical deciduous fruit belongs to the family Ebenaceae. The fruit is known as Oriental or Japanese persimmon and is commonly called as 'Japaniphal'. It is widely cultivated in warm regions of China, Japan, Korea, Brazil, Italy and Mediterranean region (Bubba et al., 2009). As per FAO report, the total world production of persimmon is more than 7.9 million tonnes of which China, Japan and Korea account $85 \%$ in 2018 (FAO, 2018). Persimmon fruit is potentially a rich source of carbohydrates, organic acids, vitamins and minerals as well as functional components such as ascorbic acid, carotenoids, polyphenolic compounds (tannins), flavanoids and flavonols. It is an excellent source of vitamin A that constitutes about $5400 \mathrm{IU}$ and minerals such as calcium $(9 \mathrm{mg} / 100 \mathrm{~g})$, phosphorus (27 mg/100 g), potassium $(203 \mathrm{mg} / 100 \mathrm{~g})$ and magnesium (11 mg/100 g) (Takekawa and Matsumoto, 2012). The ascorbic acid and total carotenoids content range from 85.63 to 102.47 and 8 to $12 \mathrm{mg} / 100 \mathrm{~g}$ on fresh weight basis, respectively (Novillo et al., 2016). The composition of pigments reveals cryptoxanthin (31\%) and lycopene (20-30\%) to be the major components of total carotene. The soluble tannins in the fruit range from $0-4 \%$ depending upon 
the ripening stage. These bioactive components acquire potential role against oxidation of LDL cholesterol, arterial stiffness that results in atherosclerotic plague formation. Further, they possess antioxidant and antimutagenic effect that activate immune response, resulting in normal functioning of metabolic activities (Butt et al., 2015). Besides being rich in various nutrients and functional components, persimmon has not yet been so far utilized for processing. Moreover, due to valuable health effects and high economic value, persimmon fruits are off late the target of increasing scientific interest. Therefore, the present investigation was undertaken to utilize persimmon for the production of RTS beverages

\section{Materials and Methods}

The fully ripe persimmon fruit (cv. Fuyu) was used for the preparation of RTS beverage. It was acquired from Regional Horticulture Research and Training Station Seobahg, Kullu, Himachal Pradesh and stored at cold store $\left(4-10^{\circ} \mathrm{C}\right)$ to maintain the shelf life. The chemicals required for the preparation of RTS beverage (citric acid) and conducting chemical analysis were acquired from Loba International Scientifics and Surgicals, Solan (HP). Other materials like sugar, glass bottles $(200 \mathrm{ml})$ were also purchased from the Solan market. The whole experiment was conducted in the Department of Food Science and Technology, UHF, Nauni, Solan, HP, India.

\subsection{Preparation of RTS beverages}

Persimmon pulp was extracted using the cold and hot pulping method according to the method standardized by (Gautam, 2020). Further, RTS beverages were prepared using both cold and hot extracted pulp by following FSSAI specification. Different combinations of persimmon pulp (10, 15 and $20 \%)$, TSS $(10,12$ and $15^{\circ}$ Brix $)$ and acidity $(0.3,0.4$ and $0.5 \%)$ were tried to prepare the beverages. The prepared product was hot filled in pre-sterilised glass bottles of $200 \mathrm{ml}$ capacity up to a rim and crown corked. Then the product was heat processed at $85{ }^{\circ} \mathrm{C}$ for $30 \mathrm{~min}$. The bottles were allowed to cool at room temperature.

\subsection{Herbal based persimmon RTS beverage}

The best RTS beverages developed using cold and hot extracted pulp was evaluated further for nutritional and sensory characteristics to select one for the preparation of flavoured persimmon RTS beverage. Similar process was followed for the preparation of flavoured persimmon RTS beverage. Ginger and ginger-mint herbal extract was used for the preparation of flavoured persimmon RTS beverage.

\subsubsection{Ginger based persimmon RTS beverage}

For the preparation of ginger-based RTS beverage, ginger extract was prepared. The fresh ginger rhizomes were washed and peeled, followed by further washing. After grating the ginger manually, the shreds were ground in a mixer and grinder (Model MX-1155) by adding water in the ratio of 1:2. The juice was then obtained by squeezing the mixture through double layer cheese cloth. The RTS beverage was prepared by replacing persimmon pulp with ginger extract in different proportions (1,3,6 and $9 \%)$. The beverages of these combinations were prepared and subjected to sensory evaluation. The best combination was selected on the basis of highest sensory scores for further storage studies.

\subsubsection{Ginger-mint based persimmon RTS beverage}

For preparation of ginger-mint based RTS beverage, ginger extract was obtained from the above process while mint extract was prepared using fresh mint leaves. The leaves were washed and ground in a mixer cum grinder. The juice was extracted by passing the mass through double layered muslin cloth. The pulp of base recipe was replaced with different concentrations of ginger-mint extract (7-6, 5-6, 3-2 and 1-1\%). The beverage, thus prepared was subjected for sensory evaluation to a panel of ten judges. The combination which got the highest overall acceptability score was selected for further storage studies.

\subsection{Storage study}

The persimmon RTS beverages were packed in glass bottles and stored at two environmental conditions, i.e., refrigerated temperature $\left(4{ }^{\circ} \mathrm{C}\right)$ and room temperature $\left(20-23{ }^{\circ} \mathrm{C}\right)$. The quality for chemical, sensory and microbial parameters were evaluated at a storage interval of $0,3,6$ months.

\subsection{Quality evaluation of persimmon RTS beverage}

\subsubsection{Chemical characteristics}

The persimmon RTS beverage was evaluated for different chemical characteristics. Total Soluble Solids (TSS) was measured using hand refractometer of ${ }^{\circ}$ Brix ranging between 0-32 (Ranganna, 2009). Titratable acidity was estimated by titrating known volume of sample against standard $0.1 \mathrm{~N} \mathrm{NaOH}$ using phenolphthalein as an indicator (Ranganna, 2009). A digital pH meter (CRISON Instrument, Ltd Spain) was used to analysis $\mathrm{pH}$ of the sample. The method given by Ranganna (2009) was used for the evaluation of sugars, ascorbic acid and $\beta$-carotene. On the other hand, total phenols were estimated as per the procedure suggested by Singleton and Rossi (1965), using gallic acid as standard. Total plate count was done under aseptically conditions, in which $0.1 \mathrm{~g}$ of serially diluted samples was inoculated on standard plate count agar medium (Ranganna, 2009). Then, the plates were incubated at $37^{\circ} \mathrm{C}$ for $72 \mathrm{~h}$ prior to counting of microbes. The results of total plate count (TPC) were expressed as $\mathrm{cfu} / \mathrm{ml}$ of sample.

\subsubsection{Sensory evaluation}

Ten semi-trained panelist was selected for sensory evaluation. The RTS beverages prepared was subjected for sensory evaluation. The persimmon RTS beverage of different combinations having a temperature of $10^{\circ} \mathrm{C}$ was subjected for sensory evaluation in order to avoid variation in sensory parameter during evaluation. Nine point Hedonic scale method given by Amerine et al. (1965) was followed for conducting the study. A panel of ten judges comprising of faculty members and post graduate students of Department of 
Food Science and Technology, Dr YS Parmar University of Horticulture and Forestry, Nauni, Solan (HP) were selected with care to evaluate the products for various sensory parameters such as colour, body, taste, aroma, consistency and overall acceptability, depending upon the type of product. Throughout, the entire period of study, efforts were made to keep the same panellist. The samples were offered to the judges in the way they are normally consumed and plain water was served to rinse their mouth in between the evaluation of samples. The samples were coded prior to presentation to judges in separate chambers or places in order to get unbiased results.

\subsubsection{Statistical analysis}

The data collected on chemical characteristics of persimmon RTS beverage as per the experiment were analysed by using completely randomized design (CRD), given by Cochran and Cox (1967) and sensory evaluations were analyzed by randomized block design (RBD), described by Mahony (1985). Further, paired t-test was also used to compare the quality of persimmon RTS beverage prepared using cold and hot extracted pulp.

\section{Results}

3.1 Standardization of recipe for persimmon RTS beverage prepared using cold and hot extracted pulp

The persimmon pulp prepared using the cold and hot pulping method was used to develop RTS beverage of different TSS. The data for different sensory attributes of beverage are highlighted in Table 1. In case of beverage prepared using cold extracted pulp, data clearly reflected that among different combinations of beverage of $10{ }^{\circ}$ Brix TSS treatment T5 (pulp $15 \%$ and $0.4 \%$ acidity) was awarded the highest (7.88) overall acceptability scores. The T5 recorded the scores of $8.25,7.50$ and 8.43 colour, consistency and taste. In different treatments of beverages of $12{ }^{\circ}$ Brix TSS, T2 treatment having combination of ( $15 \%$ pulp and $0.3 \%$ acidity) got the maximum rating for colour (8.28), consistency (7.67), taste (8.44) and (7.83) overall acceptability. The highest score was obtained by T2 (pulp $15 \%$ and acidity $0.3 \%$ ) in beverage of $15{ }^{\circ}$ Brix TSS. The sensory score was found to be $8.36,7.55,8.67$ and 7.79 for the corresponding sensory attributes. Among these treatments, beverage having TSS of $10^{\circ} \mathrm{B}, 15 \%$ pulp concentration and $0.4 \%$ acidity was selected as best.

Table 1: Sensory score of persimmon RTS beverage prepared using cold and hot extracted pulp

\begin{tabular}{|c|c|c|c|c|c|c|c|c|}
\hline \multirow{2}{*}{$\begin{array}{l}\text { Treatment } \\
\text { (Pulp:TSS:Acidity) }\end{array}$} & \multicolumn{2}{|l|}{ Colour } & \multicolumn{2}{|l|}{ Taste } & \multicolumn{2}{|c|}{ Consistency } & \multicolumn{2}{|c|}{ Overall acceptability } \\
\hline & Cold pulp & Hot pulp & Cold pulp & Hot pulp & Cold pulp & Hot pulp & Cold pulp & Hot pulp \\
\hline \multicolumn{9}{|c|}{ Beverage with TSS $10^{\circ}$ Brix } \\
\hline $\begin{array}{lll}T_{1} & (10: 0.3) \\
T_{2} & (15: 0.3) \\
T_{3} & (20: 0.3) \\
T_{4} & (10: 0.4) \\
T_{5} & (15: 0.4) \\
T_{6} & (20: 0.4) \\
T_{7} & (10: 0.5) \\
T_{8} & (15: 0.5) \\
T_{9} & (20: 0.5)\end{array}$ & $\begin{array}{l}8.15 \\
8.17 \\
8.19 \\
8.21 \\
\mathbf{8 . 2 5} \\
8.22 \\
8.14 \\
8.16 \\
8.18\end{array}$ & $\begin{array}{l}8.32 \\
8.36 \\
8.25 \\
8.34 \\
8.33 \\
8.31 \\
8.30 \\
8.28 \\
8.26\end{array}$ & $\begin{array}{l}8.32 \\
8.33 \\
8.34 \\
8.39 \\
\mathbf{8 . 4 3} \\
8.42 \\
8.31 \\
8.29 \\
8.28\end{array}$ & $\begin{array}{l}8.41 \\
8.54 \\
8.46 \\
8.40 \\
8.58 \\
8.42 \\
8.41 \\
8.45 \\
8.38\end{array}$ & $\begin{array}{l}7.42 \\
7.45 \\
7.46 \\
7.47 \\
7.50 \\
7.41 \\
7.42 \\
7.43 \\
7.44\end{array}$ & $\begin{array}{l}7.53 \\
7.54 \\
7.55 \\
7.51 \\
7.50 \\
7.48 \\
7.46 \\
7.44 \\
7.42\end{array}$ & $\begin{array}{l}7.79 \\
7.82 \\
7.83 \\
7.84 \\
7.86 \\
7.76 \\
7.78 \\
7.79 \\
7.80\end{array}$ & $\begin{array}{l}7.76 \\
7.75 \\
7.79 \\
7.73 \\
7.74 \\
7.72 \\
7.71 \\
7.72 \\
7.70\end{array}$ \\
\hline \multicolumn{9}{|c|}{ Beverage with TSS $12^{\circ}$ Brix } \\
\hline $\begin{array}{l}T_{1}(10: 0.3) \\
T_{2}(15: 0.3) \\
T_{3}(20: 0.3) \\
T_{4}(10: 0.4) \\
T_{5}(15: 0.4) \\
T_{6}(20: 0.4) \\
T_{7}(10: 0.5) \\
T_{8}(15: 0.5) \\
T_{9}(20: 0.5)\end{array}$ & $\begin{array}{l}8.22 \\
8.28 \\
8.20 \\
8.22 \\
8.23 \\
8.24 \\
8.17 \\
8.15 \\
8.14\end{array}$ & $\begin{array}{l}8.21 \\
8.38 \\
8.20 \\
8.22 \\
8.23 \\
8.24 \\
8.17 \\
8.15 \\
8.14\end{array}$ & $\begin{array}{l}8.43 \\
8.44 \\
8.42 \\
8.38 \\
8.36 \\
8.34 \\
8.32 \\
8.30 \\
8.29\end{array}$ & $\begin{array}{l}8.43 \\
8.63 \\
8.42 \\
8.38 \\
8.36 \\
8.34 \\
8.32 \\
8.30 \\
8.29\end{array}$ & $\begin{array}{l}7.65 \\
7.67 \\
7.63 \\
7.60 \\
7.58 \\
7.56 \\
7.53 \\
7.51 \\
7.50\end{array}$ & $\begin{array}{l}7.65 \\
7.67 \\
7.63 \\
7.60 \\
7.58 \\
7.56 \\
7.53 \\
7.51 \\
7.50\end{array}$ & $\begin{array}{l}7.80 \\
7.83 \\
7.82 \\
7.79 \\
7.76 \\
7.74 \\
7.75 \\
7.73 \\
7.72\end{array}$ & $\begin{array}{l}7.80 \\
7.88 \\
7.82 \\
7.79 \\
7.76 \\
7.74 \\
7.75 \\
7.73 \\
7.72\end{array}$ \\
\hline \multicolumn{9}{|c|}{ Beverage with TSS $15^{\circ}$ Brix } \\
\hline $\begin{array}{l}T_{1}(10: 0.3) \\
T_{2}(15: 0.3) \\
T_{3}(20: 0.3) \\
T_{4}(10: 0.4) \\
T_{5}(15: 0.4) \\
T_{6}(20: 0.4) \\
T_{7}(10: 0.5) \\
T_{8}(15: 0.5) \\
T_{9}(20: 0.5) \\
C D_{0.05}\end{array}$ & $\begin{array}{l}8.32 \\
8.36 \\
8.38 \\
8.34 \\
8.33 \\
8.31 \\
8.30 \\
8.28 \\
8.26 \\
\mathbf{0 . 0 0 5}\end{array}$ & $\begin{array}{l}8.15 \\
8.25 \\
8.19 \\
8.21 \\
8.17 \\
8.22 \\
8.14 \\
8.16 \\
8.18 \\
\mathbf{0 . 0 1}\end{array}$ & $\begin{array}{l}8.64 \\
8.67 \\
8.63 \\
8.65 \\
8.62 \\
8.62 \\
8.61 \\
8.59 \\
8.58 \\
\mathbf{0 . 0 0 4}\end{array}$ & $\begin{array}{l}8.32 \\
8.43 \\
8.34 \\
8.39 \\
8.33 \\
8.42 \\
8.31 \\
8.29 \\
8.28 \\
\mathbf{0 . 0 1 4}\end{array}$ & $\begin{array}{l}7.53 \\
7.55 \\
7.54 \\
7.51 \\
7.50 \\
7.48 \\
7.46 \\
7.44 \\
7.42 \\
\mathbf{0 . 0 0 5}\end{array}$ & $\begin{array}{l}7.42 \\
7.50 \\
7.46 \\
7.47 \\
7.44 \\
7.41 \\
7.42 \\
7.43 \\
7.44 \\
\mathbf{0 . 0 1 1}\end{array}$ & $\begin{array}{l}7.65 \\
7.79 \\
7.70 \\
7.68 \\
7.59 \\
7.62 \\
7.73 \\
7.61 \\
7.54 \\
\mathbf{0 . 0 0 4}\end{array}$ & $\begin{array}{l}7.79 \\
7.83 \\
7.83 \\
7.84 \\
7.82 \\
7.76 \\
7.78 \\
7.79 \\
7.80 \\
\mathbf{0 . 0 0 8}\end{array}$ \\
\hline
\end{tabular}

Where, $\mathrm{CD}_{0.05}=5 \%$ level of significance. 
On the other hand, beverage prepared using hot extracted pulp, the data showed that among different combinations of beverage of $10^{\circ}$ Brix TSS treatment T3 (pulp $20 \%$ and $0.3 \%$ acidity) was awarded the highest (7.79) overall acceptability scores. The score for other parameters were colour (8.25), consistency (7.55) and taste (8.46) which reflects the higher acceptability for $\mathrm{T} 3$ of $10^{\circ} \mathrm{B}$. In different treatments of beverages having $12{ }^{\circ} \mathrm{Brix}$ TSS, T2 treatment with combination of (15\% pulp and $0.3 \%$ acidity) got the maximum rating for colour (8.38), consistency (7.67), taste (8.63) and (7.88) overall acceptability. The highest scores in beverage of $15{ }^{\circ}$ Brix TSS was obtained by T2 (pulp $15 \%$ and acidity $0.3 \%$ ). The sensory score for other parameter was 8.25, 7.50, 8.43 and 7.83, respectively for colour, consistency, taste and overall acceptability. Among these treatments, beverage having TSS of $12{ }^{\circ}$ Brix, $15 \%$ pulp concentration and $0.3 \%$ acidity was selected as best.

\subsection{Selection of best treatment for preparation of herbal persimmon RTS beverage}

The best treatments of RTS beverage prepared from cold and hot extracted pulp was compared for the nutritional and sensory characteristics using paired t-test (Table 2). It was observed that all the parameters had significant difference which means that the mean value of the parameters were hypothetically not similar. Therefore, it reflects that cooked pulp improves the colour and consistency of the RTS beverage due to tissue breakdown and inactivation of pectinase due to heating. Further, heating causes breakdown of polysaccharides into simple sugars. Therefore, based on nutritional and sensory characteristics RTS beverage prepared using hot extracted pulp was selected for development of herbal persimmon RTS beverage and referred as $\mathrm{T}_{1}$.

Table 2: Nutritional and sensory attributes of persimmon RTS beverage

\begin{tabular}{|l|l|l|l|}
\hline Parameter & $\begin{array}{l}\text { RTS from cold } \\
\text { extracted pulp }\end{array}$ & $\begin{array}{l}\text { RTS from hot } \\
\text { extracted pulp }\end{array}$ & t-test \\
\hline TSS ( ${ }^{\circ}$ Brix) & 10 & 12 & Significant \\
Titratable acidity (\%) & 0.40 & 0.30 & Significant \\
pH & 4.07 & 4.08 & Significant \\
Total sugars (\%) & 8.40 & 10.16 & Significant \\
Reducing sugars (\%) & 6.11 & 7.20 & Significant \\
Ascorbic acid (mg/100 g) & 2.26 & 1.44 & Significant \\
$\mathbf{\beta}$-carotene (mg/100g) & 0.040 & 0.054 & Significant \\
Total phenols (mg/100 g) & 0.58 & 0.55 & Significant \\
Colour & 8.20 & 8.60 & Significant \\
Consistency & 8.00 & 8.23 & Significant \\
Taste & 8.00 & 8.23 & Significant \\
Aroma & 7.90 & 8.23 & Significant \\
Overall acceptability & 8.00 & 8.25 & Significant \\
\hline
\end{tabular}

Statistical analysis: Paired t-test at $5 \%$ level of significance.

3.3 Standardization of recipe for the preparation of herbal persimmon RTS beverage

The data regarding sensory scores of herbal RTS beverage prepared by incorporating ginger extract or a mixture of ginger and mint extract in different proportion with persimmon pulp are presented in Figure 1.
The data reflected significant difference among different treatments for all sensory attributes. Under ginger based RTS beverage $\mathrm{G}_{2}$ combination was awarded the maximum scores for colour (7.60), body (7.75), taste (8.13), aroma (8.09) and overall acceptability (8.30), followed by $\mathrm{G}_{1}$, $\mathrm{G}_{3}$ and $\mathrm{G}_{4}$. On the other hand, in case of ginger-mint based persimmon RTS beverage $\mathrm{GM}_{3}$ received maximum scores for all the sensory attributes such as colour (8.52), body (7.69), taste (7.98), aroma (7.82) and overall acceptability (8.44). Significant differences were observed among all the treatments as far as various sensory parameters are concerned. Based upon sensory evaluation, treatment $\mathrm{G}_{2}$ and $\mathrm{GM}_{3}$ was selected for further studies and referred as $\mathrm{T}_{2}$ and $\mathrm{T}_{3}$, respectively.

\subsection{Effect of nutritional and sensory attributes on persimmon} RTS beverage

The persimmon RTS beverage represented a significant difference in its storage quality when stored at different conditions for 6 months (Table 3). There was a slight increase in TSS content, $\mathrm{pH}$, total sugars, reducing sugars while decrease in titratable acidity, ascorbic acid, $\beta$-carotene and total phenols during six months storage of persimmon RTS beverage.

\subsubsection{TSS and sugars}

The data indicate a gradual increase in the TSS and sugars of RTS beverages of different treatments with the advancement of storage. During storage up to 6 months, TSS ranged from 12.00 to 12.79 ${ }^{\circ}$ Brix in ambient and 12.00 to $12.68^{\circ}$ Brix in refrigerated conditions. Among different treatments, $\mathrm{T}_{3}$ has the highest mean value (12.56 ${ }^{\circ}$ Brix) and $\mathrm{T}_{1}$ lowest (12.21 ${ }^{\circ}$ Brix). Similarly, mean value was gradually increased from 9.80 to 11.07 and 9.87 to $10.27 \%$ of total sugars and from 7.65 to 9.72 and 7.65 to $8.95 \%$ of reducing sugars under ambient and refrigerated conditions, respectively. The average value ranged from 9.62 to $10.82 \%$ and 8.07 to $9.39 \%$ for total and reducing sugars among different treatments. The interaction effect of treatment and storage conditions, are found to be significant while non-significant in TSS only. Also, the combine effect of treatment and storage condition of TSS was found to be non-significant.

\subsubsection{Titratable acidity and $\mathrm{pH}$}

There was a significant decrease in titratable acidity in all types of beverage during storage from 0.30 to $0.23 \%$ irrespective of the storage conditions. In relation to acidity, $\mathrm{pH}$ was observed to be increased with mean maximum value in treatment $\mathrm{T}_{3}$ (4.17) and minimum in $\mathrm{T}_{1}$ (4.11). The storage conditions revealed a mean value of 4.15 under ambient and 4.13 under refrigerated condition. The insignificant effect of storage condition was observed for titratable acidity. The interaction effects were found to be non-significant for storage condition and storage interval for both the parameter.

\subsubsection{Functional components}

The analysis of data shows that the storage of persimmon RTS beverage decreases its functional characteristics. The highest value for ascorbic acid and total phenols was recorded in $\mathrm{T}_{3}(2.71$ and 0.39 $\mathrm{mg} / 100 \mathrm{~g})$ while lowest in $\mathrm{T}_{1}(0.72$ and $0.36 \mathrm{mg} / 100 \mathrm{~g})$, respectively. The overall effect of storage condition (C) showed the mean value to 
be higher in refrigerated conditions $(2.01$ and $0.40 \mathrm{mg} / 100 \mathrm{~g}$ ) as compared to ambient condition ( 1.91 and $0.36 \mathrm{mg} / 100 \mathrm{~g}$ ) for the corresponding parameters. The data for $\beta$-carotene also showed a declining trend during storage period of 6 months. The mean value significantly decreased from 0.043 to $0.01 \mathrm{mg} / 100 \mathrm{~g}$ under ambient while 0.043 to $0.013 \mathrm{mg} / 100 \mathrm{~g}$ under refrigerated condition. The mean maximum value of $0.04 \mathrm{mg} / 100 \mathrm{~g}$ was recorded in $\mathrm{T}_{1}$ during storage. An interaction effect was found to be significant while the combined effect of treatments, a storage interval and storage condition was found to be non-significant in case of total phenols and $\beta$-carotene.

\subsubsection{Sensory score}

The sensory score have significant difference among treatment and was also affected during storage as shown in Figures 2, 3 and 4. The colour scores of treatment $T_{1}$ had higher score (8.60) while taste (8.72), aroma (8.25) and consistency (8.32) score was highest in $\mathrm{T}_{3}$ at 0 month of storage. The effect of storage condition reflected the mean colour score of 7.82, taste score of 7.69, aroma score of 7.71 and consistency score of 7.69 in refrigerated condition and 7.78, $7.68,7.62$ and 7.59, respectively at ambient condition. The overall effect of storage period depicts decrease in score from 8.32 to 7.28 for colour, 8.47 to 6.84 for taste, 8.20 to 7.01 for aroma and 8.23 to 6.77. An interaction of treatments, storage interval and storage condition was noticed to be non-significant for colour and taste and the combined effect of treatment and storage condition was found to be non-significant for taste. The mean score of overall acceptability of persimmon RTS beverage was significantly decreased from 8.31 to 6.76 during storage for 6 months. Treatment $\mathrm{T}_{3}$ got the maximum score which was at par with $\mathrm{T}_{1}$. Further storage of beverage under refrigerated condition maintained the quality of the beverage to higher extent in comparison to room temperature condition. The interaction effect of treatment, storage interval and storage condition and combine effect of treatment and storage condition was noticed to be non-significant.

Table 3: Effect of storage on chemical characteristics of persimmon RTS beverage

\begin{tabular}{|c|c|c|c|c|c|c|c|c|c|c|c|c|c|c|}
\hline \multirow[t]{2}{*}{ Parameters } & \multirow{2}{*}{$\begin{array}{l}\text { Packaging } \\
\text { material }\end{array}$} & \multicolumn{3}{|c|}{ Room temperature } & \multirow[t]{2}{*}{ Mean } & \multicolumn{3}{|c|}{ Refrigerated temperature } & \multirow[t]{2}{*}{ Mean } & \multicolumn{3}{|c|}{$\mathrm{T} \times \mathrm{S}$ interaction table } & \multirow[t]{2}{*}{ Mean } & \multirow[t]{2}{*}{$C D_{0.05}$} \\
\hline & & \begin{tabular}{|l|}
0 \\
months
\end{tabular} & \begin{tabular}{|l|} 
\\
months
\end{tabular} & \begin{tabular}{|l|}
6 \\
months \\
\end{tabular} & & \begin{tabular}{|l} 
\\
months \\
\end{tabular} & \begin{tabular}{|l|}
3 \\
months \\
\end{tabular} & \begin{tabular}{|l|}
6 \\
months
\end{tabular} & & \begin{tabular}{|l|}
0 \\
months \\
\end{tabular} & \begin{tabular}{|l} 
\\
months \\
\end{tabular} & $\begin{array}{l}6 \\
\text { months }\end{array}$ & & \\
\hline $\begin{array}{l}\text { Total } \\
\text { soluble } \\
\text { solids } \\
\left({ }^{\circ} \mathrm{B}\right)\end{array}$ & $\begin{array}{l}\text { T1 } \\
\text { T2 } \\
\text { T3 } \\
\text { Mean }\end{array}$ & $\begin{array}{l}12.00 \\
12.00 \\
12.00 \\
12.00\end{array}$ & $\begin{array}{l}12.30 \\
12.60 \\
12.68 \\
12.53\end{array}$ & $\begin{array}{l}12.40 \\
12.86 \\
13.10 \\
12.79\end{array}$ & $\begin{array}{l}12.24 \\
12.50 \\
12.60 \\
\mathbf{1 2} .44\end{array}$ & $\begin{array}{l}12.00 \\
12.00 \\
12.00 \\
12.00\end{array}$ & $\begin{array}{l}12.25 \\
12.51 \\
12.61 \\
12.46\end{array}$ & $\begin{array}{l}12.33 \\
12.72 \\
12.98 \\
12.68\end{array}$ & $\begin{array}{l}12.20 \\
12.41 \\
12.53 \\
\mathbf{1 2 . 3 8}\end{array}$ & $\begin{array}{l}12.00 \\
12.00 \\
12.00 \\
2.00\end{array}$ & $\begin{array}{l}12.28 \\
12.55 \\
12.65 \\
\mathbf{1 2 . 5 0}\end{array}$ & $\begin{array}{l}12.36 \\
12.80 \\
13.04 \\
\mathbf{1 2 . 7 3}\end{array}$ & $\begin{array}{l}12.21 \\
12.45 \\
12.56\end{array}$ & $\begin{array}{l}T=0.013 \\
C=0.011 \\
S=0.013 \\
T \times C \times S=N S\end{array}$ \\
\hline $\begin{array}{l}\text { Titratable } \\
\text { acidity } \\
(\%)\end{array}$ & $\begin{array}{l}\text { T1 } \\
\text { T2 } \\
\text { T3 } \\
\text { Mean }\end{array}$ & $\begin{array}{l}0.30 \\
0.30 \\
0.30 \\
0.30\end{array}$ & $\begin{array}{l}0.23 \\
0.26 \\
0.25 \\
0.25\end{array}$ & $\begin{array}{l}0.20 \\
0.24 \\
0.23 \\
0.23\end{array}$ & $\begin{array}{l}0.25 \\
0.27 \\
0.26 \\
0.26\end{array}$ & $\begin{array}{l}0.30 \\
0.30 \\
0.30 \\
0.30\end{array}$ & $\begin{array}{l}0.20 \\
0.28 \\
0.27 \\
0.25\end{array}$ & $\begin{array}{l}0.18 \\
0.26 \\
0.25 \\
0.23\end{array}$ & $\begin{array}{l}0.23 \\
0.28 \\
0.27 \\
\mathbf{0 . 2 6}\end{array}$ & $\begin{array}{l}0.30 \\
0.30 \\
0.30 \\
0.30\end{array}$ & $\begin{array}{l}0.22 \\
0.27 \\
0.26 \\
0.25\end{array}$ & $\begin{array}{l}0.19 \\
0.25 \\
0.24 \\
0.23\end{array}$ & $\begin{array}{l}\mathbf{0 . 2 4} \\
0.27 \\
0.27\end{array}$ & $\begin{array}{l}\mathrm{T}=0.014 \\
\mathrm{C}=\mathrm{NS} \\
\mathrm{S}=0.014 \\
\mathrm{~T} \times \mathrm{CxS}=\mathrm{NS}\end{array}$ \\
\hline pH & $\begin{array}{l}\text { T1 } \\
\text { T2 } \\
\text { T3 } \\
\text { Mean }\end{array}$ & $\begin{array}{l}4.08 \\
4.11 \\
4.14 \\
4.11\end{array}$ & $\begin{array}{l}4.12 \\
4.14 \\
4.18 \\
4.15\end{array}$ & $\begin{array}{l}4.16 \\
4.18 \\
4.22 \\
4.19\end{array}$ & $\begin{array}{l}4.12 \\
4.15 \\
4.18 \\
4.15\end{array}$ & $\begin{array}{l}4.08 \\
4.11 \\
4.14 \\
4.11\end{array}$ & $\begin{array}{l}4.10 \\
4.12 \\
4.16 \\
4.13\end{array}$ & $\begin{array}{l}4.13 \\
4.15 \\
4.19 \\
4.16\end{array}$ & $\begin{array}{l}4.11 \\
4.13 \\
4.17 \\
4.13\end{array}$ & $\begin{array}{l}4.08 \\
4.11 \\
4.14 \\
4.11\end{array}$ & $\begin{array}{l}4.11 \\
4.13 \\
4.17 \\
4.14\end{array}$ & $\begin{array}{l}4.15 \\
4.17 \\
4.21 \\
4.17\end{array}$ & $\begin{array}{l}4.11 \\
4.14 \\
4.17\end{array}$ & $\begin{array}{l}T=0.014 \\
C=0.011 \\
S=0.014 \\
T x C x S=N S\end{array}$ \\
\hline $\begin{array}{l}\text { Total } \\
\text { sugars } \\
(\%)\end{array}$ & $\begin{array}{l}\text { T1 } \\
\text { T2 } \\
\text { T3 } \\
\text { Mean }\end{array}$ & $\begin{array}{l}10.16 \\
9.28 \\
9.95 \\
9.80\end{array}$ & $\begin{array}{l}11.38 \\
9.53 \\
10.20 \\
10.37\end{array}$ & $\begin{array}{l}12.51 \\
10.02 \\
10.69 \\
11.07\end{array}$ & $\begin{array}{l}11.35 \\
9.61 \\
10.23 \\
\mathbf{1 0 . 4 2}\end{array}$ & $\begin{array}{l}10.16 \\
9.52 \\
9.95 \\
9.87\end{array}$ & $\begin{array}{l}10.31 \\
9.49 \\
10.16 \\
9.99\end{array}$ & $\begin{array}{l}10.39 \\
9.87 \\
10.54 \\
10.27\end{array}$ & $\begin{array}{l}10.29 \\
9.63 \\
10.22 \\
\mathbf{1 0 . 0 5}\end{array}$ & $\begin{array}{l}10.16 \\
9.40 \\
9.95 \\
9.84\end{array}$ & $\begin{array}{l}10.84 \\
9.51 \\
10.18 \\
\mathbf{1 0 . 1 8}\end{array}$ & $\begin{array}{l}11.45 \\
9.95 \\
10.61 \\
\mathbf{1 0 . 6 7}\end{array}$ & $\begin{array}{l}10.82 \\
9.62 \\
10.25\end{array}$ & $\begin{array}{l}T=0.068 \\
C=0.056 \\
S=0.068 \\
T x C x S=0.167\end{array}$ \\
\hline $\begin{array}{l}\text { Reducing } \\
\text { sugars } \\
(\%)\end{array}$ & $\begin{array}{l}\text { T1 } \\
\text { T2 } \\
\text { T3 } \\
\text { Mea n }\end{array}$ & $\begin{array}{l}7.20 \\
7.20 \\
8.53 \\
7.65\end{array}$ & $\begin{array}{l}9.50 \\
8.25 \\
9.27 \\
9.01\end{array}$ & $\begin{array}{l}9.67 \\
9.02 \\
10.46 \\
9.72\end{array}$ & $\begin{array}{l}8.80 \\
8.16 \\
9.42 \\
\mathbf{8 . 8 0}\end{array}$ & $\begin{array}{l}7.20 \\
7.20 \\
8.53 \\
7.65\end{array}$ & $\begin{array}{l}7.35 \\
8.20 \\
9.22 \\
8.26\end{array}$ & $\begin{array}{l}7.52 \\
8.97 \\
10.34 \\
8.95\end{array}$ & $\begin{array}{l}7.36 \\
8.13 \\
9.36 \\
8.28\end{array}$ & $\begin{array}{l}7.20 \\
7.20 \\
8.53 \\
7.65\end{array}$ & $\begin{array}{l}8.43 \\
8.23 \\
9.25 \\
8.63\end{array}$ & $\begin{array}{l}8.60 \\
8.99 \\
10.40 \\
9.33\end{array}$ & $\begin{array}{l}8.07 \\
8.14 \\
9.39\end{array}$ & $\begin{array}{l}T=0.014 \\
C=0.012 \\
S=0.014 \\
T \times C x S=0.035\end{array}$ \\
\hline $\begin{array}{l}\text { Ascorbic } \\
\text { acid } \\
(\mathrm{mg} / 100 \mathrm{~g})\end{array}$ & $\begin{array}{l}\text { T1 } \\
\text { T2 } \\
\text { T3 } \\
\text { Mean }\end{array}$ & $\begin{array}{l}1.443 \\
2.753 \\
3.073 \\
2.423\end{array}$ & $\begin{array}{l}0.243 \\
2.573 \\
2.783 \\
1.867\end{array}$ & $\begin{array}{l}0.143 \\
1.953 \\
2.183 \\
1.427\end{array}$ & $\begin{array}{l}0.61 \\
2.43 \\
2.68 \\
\mathbf{1 . 9 1}\end{array}$ & $\begin{array}{l}1.443 \\
2.753 \\
3.073 \\
2.423\end{array}$ & $\begin{array}{l}0.643 \\
2.613 \\
2.853 \\
2.037\end{array}$ & $\begin{array}{l}0.393 \\
2.030 \\
2.323 \\
1.582\end{array}$ & $\begin{array}{l}0.83 \\
2.46 \\
2.75 \\
\mathbf{2 . 0 1}\end{array}$ & $\begin{array}{l}1.44 \\
2.75 \\
3.07 \\
2.42\end{array}$ & $\begin{array}{l}0.44 \\
2.59 \\
2.81 \\
\mathbf{1 . 9 5}\end{array}$ & $\begin{array}{l}0.27 \\
1.99 \\
2.25 \\
\mathbf{1 . 5 0}\end{array}$ & $\begin{array}{l}0.72 \\
2.44 \\
2.71\end{array}$ & $\begin{array}{l}S=0.014 \\
T=0.014 \\
C=0.012 \\
T \times C x S=0.035\end{array}$ \\
\hline $\begin{array}{l}\beta \text {-carotene } \\
(\mathrm{mg} / 100 \mathrm{~g})\end{array}$ & $\begin{array}{l}\text { T1 } \\
\text { T2 } \\
\text { T3 } \\
\text { Mean }\end{array}$ & $\begin{array}{l}0.054 \\
0.037 \\
0.037 \\
0.043\end{array}$ & $\begin{array}{l}0.034 \\
0.023 \\
0.024 \\
0.027\end{array}$ & $\begin{array}{l}0.024 \\
0.003 \\
0.003 \\
0.010\end{array}$ & $\begin{array}{l}0.038 \\
0.021 \\
0.022 \\
\mathbf{0 . 0 2 7}\end{array}$ & $\begin{array}{l}0.054 \\
0.037 \\
0.037 \\
0.043\end{array}$ & $\begin{array}{l}0.043 \\
0.028 \\
0.030 \\
0.034\end{array}$ & $\begin{array}{l}0.031 \\
0.003 \\
0.004 \\
0.013\end{array}$ & $\begin{array}{l}0.043 \\
0.023 \\
0.024 \\
\mathbf{0 . 0 3 0}\end{array}$ & $\begin{array}{l}0.054 \\
0.037 \\
0.037 \\
\mathbf{0 . 0 4 3}\end{array}$ & $\begin{array}{l}0.039 \\
0.026 \\
0.027 \\
\mathbf{0 . 0 3 1}\end{array}$ & $\begin{array}{l}0.028 \\
0.003 \\
0.004 \\
\mathbf{0 . 0 1 2}\end{array}$ & $\begin{array}{l}0.040 \\
0.022 \\
0.023\end{array}$ & $\begin{array}{l}\mathrm{T}=0.002 \\
\mathrm{C}=0.001 \\
\mathrm{~S}=0.002 \\
\mathrm{~T} \times \mathrm{CxS}=\mathrm{NS}\end{array}$ \\
\hline $\begin{array}{l}\text { Phenols } \\
(\mathrm{mg} / 100 \mathrm{~g})\end{array}$ & $\begin{array}{l}\text { T1 } \\
\text { T2 } \\
\text { T3 } \\
\text { Mean }\end{array}$ & $\begin{array}{l}0.55 \\
0.58 \\
0.60 \\
0.58\end{array}$ & $\begin{array}{l}0.25 \\
0.35 \\
0.37 \\
0.33\end{array}$ & $\begin{array}{l}0.18 \\
0.14 \\
0.16 \\
0.16\end{array}$ & $\begin{array}{l}0.33 \\
0.36 \\
0.38 \\
\mathbf{0 . 3 6}\end{array}$ & $\begin{array}{l}0.55 \\
0.58 \\
0.60 \\
0.58\end{array}$ & $\begin{array}{l}0.38 \\
0.37 \\
0.42 \\
0.39\end{array}$ & $\begin{array}{l}0.26 \\
0.18 \\
0.19 \\
0.21\end{array}$ & $\begin{array}{l}0.40 \\
0.38 \\
0.41 \\
\mathbf{0 . 4 0}\end{array}$ & $\begin{array}{l}0.55 \\
0.58 \\
0.60 \\
\mathbf{0 . 5 8}\end{array}$ & $\begin{array}{l}0.32 \\
0.36 \\
0.40 \\
\mathbf{0 . 3 6}\end{array}$ & $\begin{array}{l}0.22 \\
0.16 \\
0.18 \\
\mathbf{0 . 1 8}\end{array}$ & $\begin{array}{l}\mathbf{0 . 3 6} \\
0.37 \\
0.39\end{array}$ & $\begin{array}{l}T=0.017 \\
C=0.014 \\
S=0.017 \\
T \times C x S=N S\end{array}$ \\
\hline
\end{tabular}

Where, $\mathrm{T}=$ Treatment, $\mathrm{C}=$ Storage condition, $\mathrm{S}=$ Storage interval, $\mathrm{CD}_{0.05}=5 \%$ level of significance. 


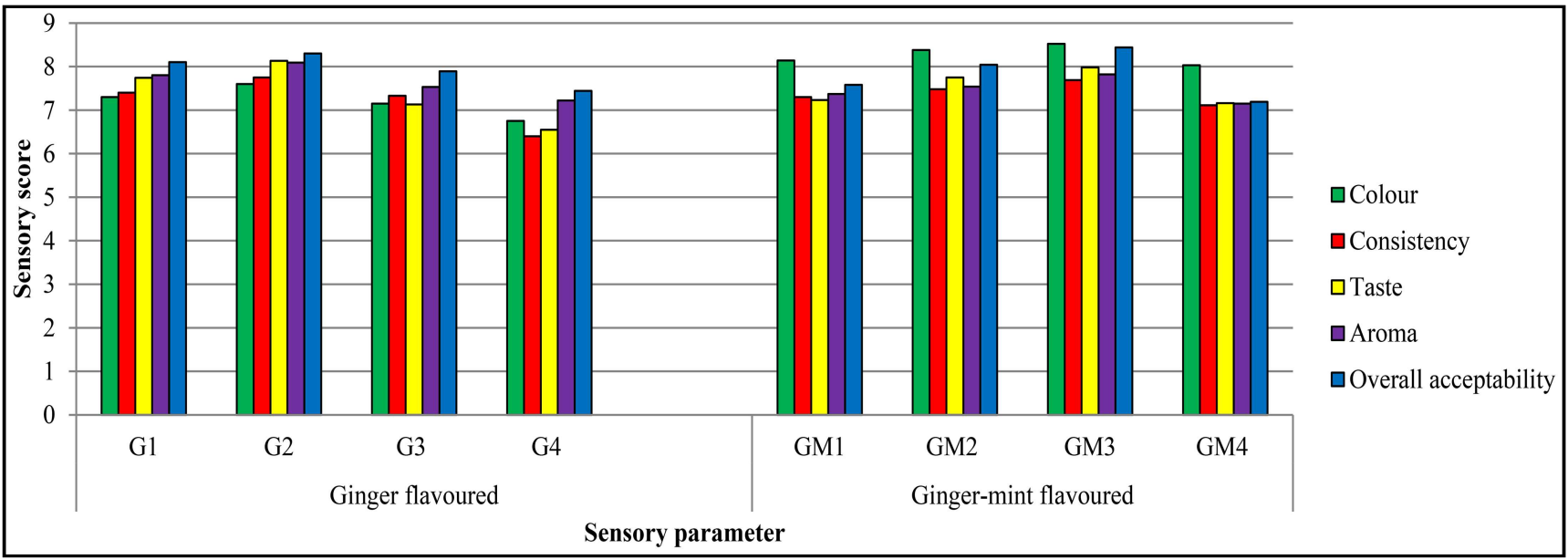

Figure 1: Sensory score* of flavoured persimmon RTS beverage

Statistical analysis: Values are average of sensory score analysed by RBD three factors ANOVA.

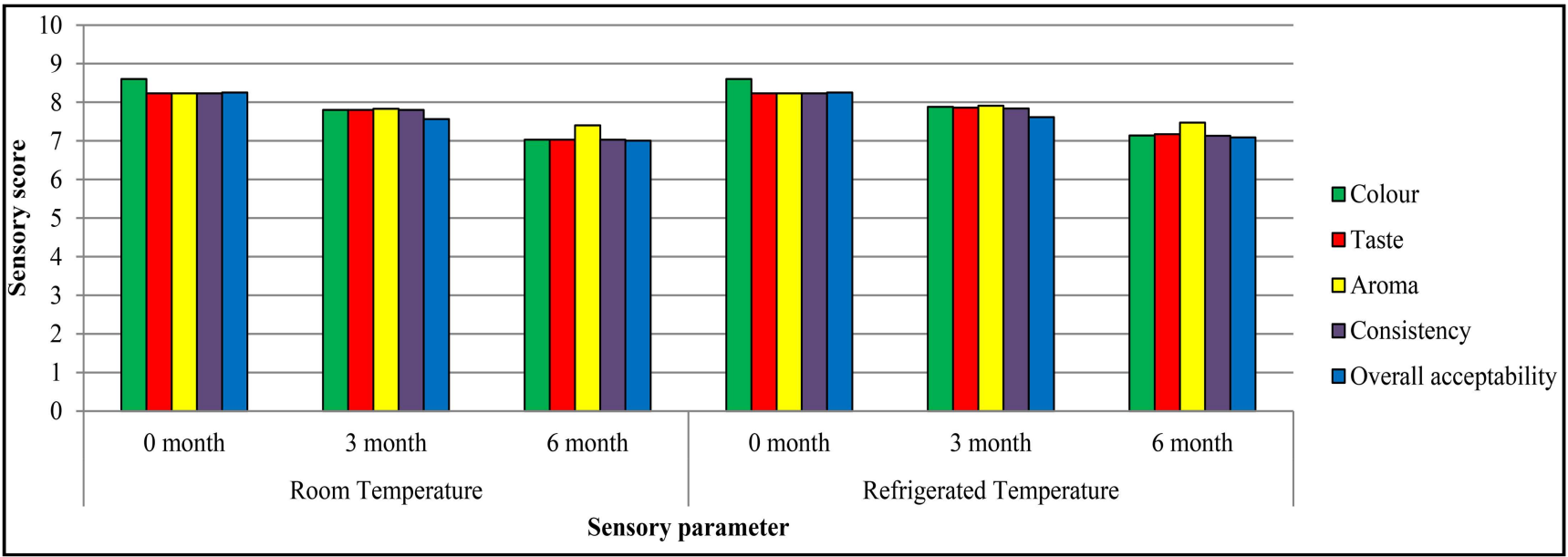

Figure 2: Effect of storage on sensory score* of persimmon RTS beverage

Statistical analysis: Values are average of sensory score analysed by RBD three factors ANOVA.

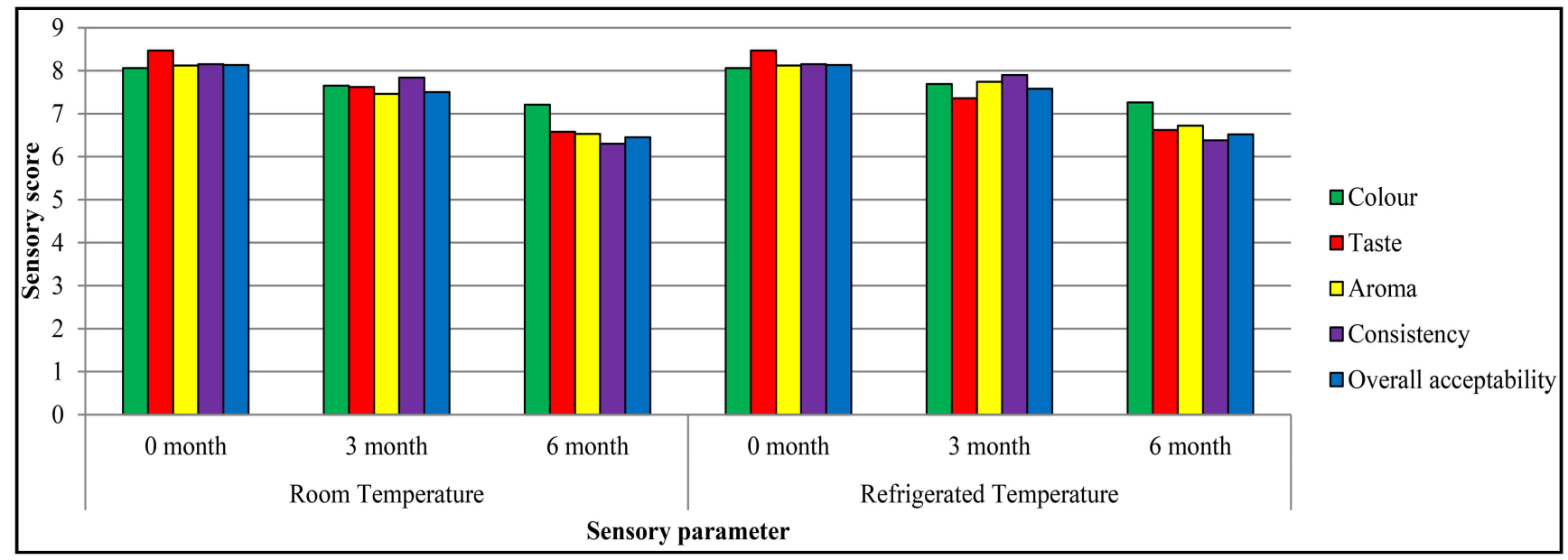

Figure 3: Effect of storage on sensory score* of ginger flavoured persimmon RTS beverage

Statistical analysis: Values are average of sensory score analysed by RBD three factors ANOVA. 


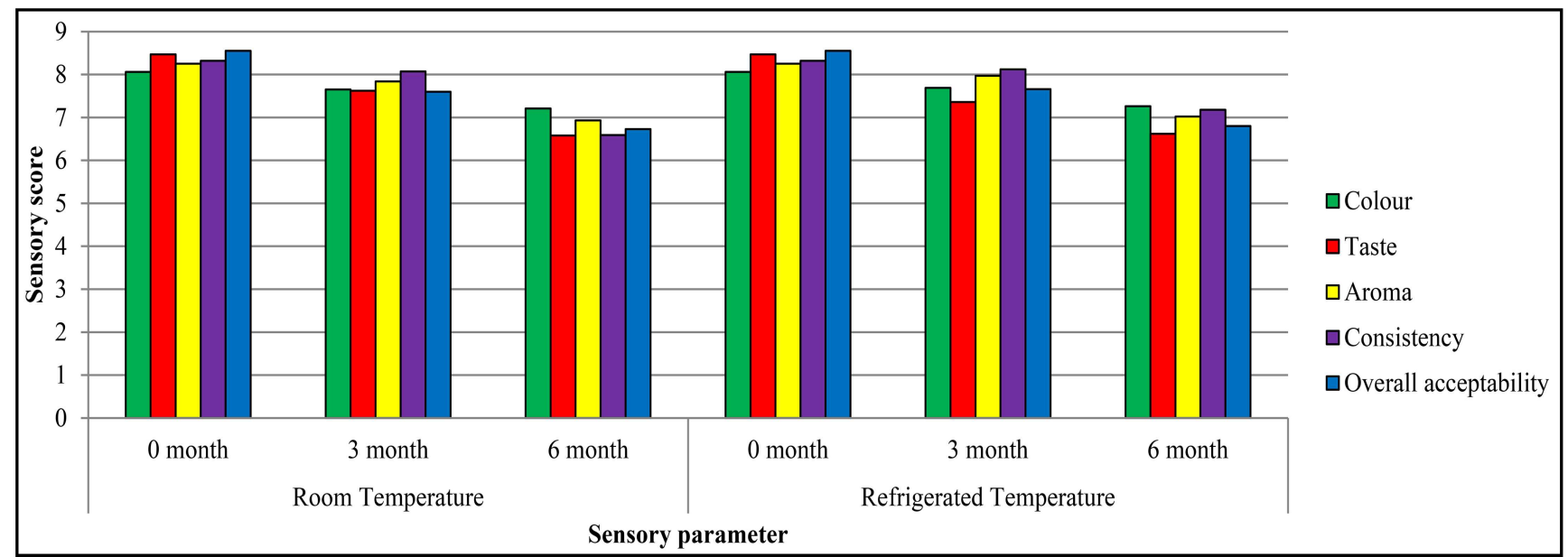

Figure 4: Effect of storage on sensory score* of ginger-mint flavoured persimmon RTS beverage

Statistical analysis: Values are average of sensory score analysed by RBD three factors ANOVA.

\subsubsection{Changes in microbial population $\left(1 \times 10^{2} \mathrm{cfu} / \mathrm{ml}\right)$ of persimmon RTS beverage prepared using pulp of hot pulping method}

The data for microbial count of persimmon RTS beverages prepared and stored under ambient and refrigerated condition for a period of 6 months, revealed no microbial growth in all the treatments at 0 month. However, a few microbial growths were observed during storage but the count was below safe limits of FSSAI, 2006. Therefore, the product was considered as safe for consumption.

\section{Discussion}

In case of beverage prepared using cold extracted pulp, the score of colour and taste was improved with increase in TSS up to pulp concentration of $15 \%$. The consistency was found to be better of the beverages having TSS of $12{ }^{\circ} \mathrm{Brix}$ and pulp concentration up to $15 \%$. With increase in pulp concentration, the overall acceptability was high at lower level of acidity but when the acidity of beverage is increased to $0.5 \%$, it decreased. Also increase in TSS decreases the overall acceptability of the beverages. Similarly in RTS beverage prepared using hot extracted pulp, taste was found to be improved by increasing TSS up to $12{ }^{\circ} \mathrm{Brix}$, pulp concentration $15 \%$ and acidity $0.4 \%$. With increase in pulp concentration consistency and overall acceptability was increased at lower level of acidity but when the acidity of beverage is increased, it decreased. Also at $12^{\circ}$ Brix TSS, the overall acceptability of the beverages was highest and gets decreased with either increase or decrease in TSS. In a similar manner, Dhiman et al. (2017) formulated pumpkin based RTS beverage involving $15 \%$ pulp, $13{ }^{\circ} \mathrm{B}$ TSS and $0.3 \%$ acidity while Hamid et al. (2017) developed RTS beverage using $14 \%$ mulberry fruits, at $12{ }^{\circ}$ Brix TSS and $0.3 \%$ acidity. Thakur et al. (2020) prepared RTS beverage from wild prickly pear fruits having $12{ }^{\circ}$ Brix TSS, $14 \%$ juice and $0.03 \%$ acidity.

During 6 month of storage, the increase in TSS and total sugars during storage might be due to the solubilisation of solids present in the juice and another reason might be the conversion of polysaccharides into simple sugar (Anita, 2012). Increase in reducing sugars during storage might be due to the hydrolysis of starch into sugars and more increase under ambient conditions which might be due to the faster rate of reaction because higher temperature (Heikal et al., 1964). The decrease in titratable acidity during storage might be due to co-polymerization of organic acids with sugars and amino acids and loss of volatile acids during storage (Krishnaveni et al., 2001). The present findings are in conformity with Krishnaveni et al. (2001) in jack fruit, Deka et al. (2004) in lime-aonla, Satkar et al. (2013) in bittergourd RTS beverage, Thakur and Thakur (2017) in box myrtle drink, Thakur et al. (2018) in wild aonla drink and Hamid et al. (2017) in mulberry drink during storage. Also, Sashikumar et al. (2013) found an increasing trend of TSS and decrease in titratable acidity during storage of therapeutic ready-to-serve made from blends of Aloe-vera, aonla and ginger juice, Sirohi et al. (2010) in whey based mango-herbal (pudina) beverage, Bhagwan and Awadesh (2014) in mango-ginger RTS, Dhiman et al., (2017) for pumpkin RTS beverages and Chandra et al. (2018) for aloe-vera, mint and ginger RTS beverage.

Further, degradation into dehydroascorbic acid or furfural during storage might have caused decrease in ascorbic acid in persimmon RTS beverage. Degradation is more under ambient conditions as, ascorbic acid is highly sensitive to heat. Also, according to Jaiswal et al. (2008), the oxidation of irreversible conversion of L-ascorbic acid into dehydroascorbic acid oxidase caused by trapped or residual oxygen in the glass bottles causes loss in ascorbic acid. Decrease in $\beta$-carotene might be due to the auto-oxidative degradation during processing and storage of food or due to oxidative breakdown, isomerization or enzymatic destruction of the pigments (Alkesh, 2005). Involvement of phenols in the formation of polymeric compounds complex of phenols with protein and their subsequent precipitations leads to significant decrease in total phenols during storage. The results for ascorbic acid, total phenols and $\beta$-carotene of the study are in accordance with the findings of Yadav et al. (2014) in guava-mango drink, Thakur and Thakur (2017) in box myrtle drink, 
Satkar et al. (2015) in bitter gourd drink, Thakur et al. (2018) in wild aonla drink, Dhiman et al., (2017) for pumpkin RTS beverages and Hamid et al. (2017) in mulberry drink. Even in case of herbal RTS beverage, decreasing trend was observed by Tiwari (2000) in guavapapaya RTS, Sindumathi and Premalatha (2015) in papaya-pineapple flavoured RTS, Sirohi et al. (2010) in whey based mango-herbal (pudina) beverage, Bhagwan and Awadesh (2014) in mango-ginger RTS, Dhiman et al. (2017) for pumpkin RTS beverages, Chandra et al. (2018) for Aloe-vera, mint and ginger RTS beverage and Sharma et al. (2019) for apple-whey based herbal functional RTS beverage.

\section{Conclusion}

The study showed that the RTS beverages prepared using pulp extracted by cold pulping method of treatment T5 $\left(10^{\circ}\right.$ Brix TSS + $15 \%$ pulp $+0.4 \%$ acidity) and RTS beverage prepared using pulp extracted by hot pulping of treatment T1 $\left(12^{\circ}\right.$ Brix TSS $+15 \%$ pulp $+0.3 \%$ acidity), was found to be the best. Herbal persimmon RTS beverage prepared from persimmon pulp using ginger and ginger-mint extract was most liked by the panellists with the mean overall acceptability score of 8.30 and 8.44. Among different RTS beverage, the highest $\beta$-carotene $(0.023 \mathrm{mg} / 100 \mathrm{~g})$, ascorbic acid $(2.71 \mathrm{mg} / 100 \mathrm{~g})$ and total phenols $(0.39 \mathrm{mg} / 100 \mathrm{~g})$ was recorded in ginger-mint base persimmon RTS beverage. Henceforth, it is concluded that persimmon fruit is highly nutritious crop, but is utilized to a very limited extent for processing. The non-astringent Fuyu persimmon (D. kaki) can be converted into pulp and utilized for the preparation of nutritionally enriched persimmon RTS beverage of remunerative cost.

\section{Conflict of interest}

The authors declare that there are no conflicts of interest in the course of conducting the research. All the authors had final decision regarding the manuscript and decision to submit the findings for publication.

\section{References}

Alam, A. (2019). Herbs that heal spices: The hoard of natural remedies. Ann. Phytomed., 8(2):7-18.

Alkesh (2005). Production of carotenoids as food colourants from natural sources. PhD Thesis. Dr Y S Parmar University of Horticulture and Forestry, Solan, HP.

Amerine, M.A.; Pangborn, R.M. and Roessler, E.B. (1965). Principles of sensory evaluation of food. In: Food science and technology: A serious of monographs. Academic Press, New York, London. pp:27-72.

Anita, K. (2012). Nutritional quality, functional properties and value addition of underutilized fruits of Himachal Pradesh. PhD Thesis. Chaudhary Sarwan Kumar Himachal Pradesh Krishi Vishvavidyalaya, Palampur, HP.

Bhagwan, D. and Awadhesh, K. (2014). Development and storage of mango ginger RTS beverage. Int. J. Food, Agri. Vet. Sci., 4(3):15-20

Bubba, M.D.; Giordani, E.; Pippucci, L.; Cincinelli, A.; Checchini, L. and Galvan, P. (2009). Changes in tannins, ascorbic acid and sugar contents in astringent persimmon during on-tree growth and ripening and in response to different post harvest treatments. J. Food Compos. Anal., 22:668-677.
Butt, M.S.; Sultan, M.T.; Aziz, M.; Naz, A.; Ahmed, W.; Kumar, N. and Imran, N. (2015). Persimmon (Diospyros kaki) fruit: Hidden phytochemicals and health claims. Exp. Clin. Sci. J., 14:542-561.

Chandra, N.; Sarkar, S.; Singha, R. and Sharma, B. (2018). Development and evaluation of ready to serve beverage (RTS) from blend of awala, aloe-vera, mint and ginger. Int. J. Curr. Microbiol. Appl. Sci., 7:3467-3472.

Cochran, W.G. and Cox, C.M. (1967). Experimental design. John Wiley and Sons, New York. pp:171-217.

Deka, B.C.; Sethi, V.; Suneja, P. and Shrivastava, V.K. (2004). Physico-chemical changes of lime aonla spiced beverage during storage. J. Food Sci. Technol., 41:329-332.

Dhiman, A.K.; Babu, G.N.; Attri, S. and Ramachandran, P. (2017). Development and standardization of ripe pumpkin based squash and its stability during storage. Int. J. Curr. Microbiol. Appl. Sci., 10:821-831.

FAO (2018). FAO statistical database. Food and Agriculture Organisation. http://faostat.fao.org. [11:30 AM; 25 th August 2019].

Gautam, A. (2020). Ready-to-serve (RTS) beverages from persimmon (Diospyros kaki L.). M.Sc Thesis, Dr Y S Parmar Univeristy of Horticulture and Forestry, Solan, HP.

Hamid; Thakur, N.S.; Kumar, P. and Thakur, A. (2017). Studies on preparation and preservation of ready-to-serve (RTS) beverage from underutilized mulberry (Morus alba L.) fruits and its quality evaluation during storage. Int. J. Curr. Microbiol. Appl. Sci., 6:1067-1079.

Heikal, H.A.; Wakeil, E.L.; Foda, I.O. and Ashmawi, H. (1964). Preservation of lemon juice. Agric. Res. Rev., 42:68.

Jaiswal, R.; Singh, G. and Singh, A. K. (2008). Evaluation of aonla (Emblica officinalis G.) cultivars for squash making. Progressive Agriculture, 8:29-31.

Karishnaveni, A.; Megalai, G.M. and Saravanikumar, R. (2001). Storage stability of jackfruit (Artocarpus heterophyllus) RTS beverage. J. Food Sci. Technol., 38:601-602.

Mahony, M.O. (1985). Sensory evaluation of food. In: Statistical methods and procedures. Marcel Dekker Inc., New York.

Nguyen, M.P. (2020). Processing of dragon fruit beverage by acoustic treatment. Ann. Phytomed., 9(1):129-132.

Novillo, P.; Salvador, A.; Crisosto, C. and Besada, C. (2016). Influence of persimmon astringency type on physico-chemical changes from the green stage to commercial harvest. Scientia Hort., 206:7-14.

Ranganna, S. (2009). Handbook of analysis and quality control for fruit and vegetable products. Tata McGraw Hill, New Delhi, pp:112.

Sashikumar, R.; Ramesh, C.R.; Prodyut, K.P. and Suresh, C.P. (2013). Development and storage studies of therapeutic ready-to-serve beverage made from blend of aloe-vera, aonla and ginger juice. Food Process Technol., 4:6.

Satkar, K.P.; Kotecha, P.M. and Thorat, S.S. (2015). Process standardization for preparation of health drink from bittergourd. Beverage and Food World, 42:50-52.

Satkar, K.P.; Kulthe, A.A. and Chalke, P.R. (2013). Preparation of bitter gourd ready-to-serve beverage and effect of storage temperature on its keeping quality. The Bioscan, 8:115-117.

Sharma, R.; Choudhary R.; Thakur, N.S. and Thakur, A. (2019). Development and quality of apple-whey based herbal functional ready-to-serve beverage. J. Appl. Nat. Sci., 11(2):291-298. 
Sindumathi, G. and Premalatha, M.R. (2015). Development and storage studies of naturally flavored papaya-pineapple blended ready-to-serve (RTS) beverages. Int. J. Sci. Res., 4:856-860.

Singelton, V.L. and Rossi, J.A. (1965). Colorimetry of total phenolics with phosphomolybedic phosphotungstic acid reagent. Am. J. Enol. Vitic., 16:144-158.

Sirohi, D.; Choudhary, P.L.; Patel, S. and Sahu, C. (2010). Physicochemical and sensory characteristics of whey based mango-herbal (pudina) beverage. Beverage and Food World, 5:44-46.

Takekawa, K. and Matsumoto, K. (2012). Water insoluble condensed tannins content of young persimmon fruit-derived crude fibre relates to its bile acid-binding ability. Nat. Prod. Res., 26:2255-2258.

Thakur, N.S. and Thakur. A. (2017). Development of squash from box myrtle (Myricanagi) and its quality evaluation during storage. Journal of Hill Agriculture, 8:87-92.
Thakur, N.S.; Chauhan, M. and Thakur, A. (2020). Studies on development and storage quality evaluation of betalains rich drink prepared from wild prickly pear (Opuntia dillenii haw.) fruits. The bioscan, 15(1):009-013.

Thakur, N.S.; Thakur, N.; Hamid; Kumar, P. and Thakur, A. (2018). Formulation and optimization of vitamin C Rich ready-to-serve juice based beverage from wild aonla fruits and its quality evaluation during storage. J. Pharmacogn. Phytochem., 7:1796-1802.

Tiwari, R.B. (2000). Studies on blending of guava and papaya pulp for RTS beverages. Indian Food Packer, 54:68-72.

Yadav, S.; Gehlot, R.; Siddiqui, S. and Grewal,R.B. (2014). Changes in chemical constituents and overall acceptability of guava-mango ready-to-serve (RTS) drink and squash. Beverage and Food World, 41:30-33.

Citation Anjali Gautam, Anju K. Dhiman, Surekha Attri and Deepika Kathuria (2020). Formulation and storage studies of herbal based RTS beverages from persimmon (Diospyros kaki L.) fruit. Ann. Phytomed., 9(2):155-163. http://dx.doi.org/ 10.21276/ap.2020.9.2.13 